\title{
The fungal spores elimination in drinking water by $\mathrm{UV}$ radiation
}

\author{
${ }^{1}$ L. Tóthová and ${ }^{2} E$. Franková \\ 'Water Research Institute, Bratislava, Slovak Republic \\ ${ }^{2}$ Department of Sanitary Engineering, Faculty of Civil Engineering, \\ Slovak University of Technology, Bratislava, Slovak Republic
}

\begin{abstract}
UV radiation is effective on all microbial forms in water but lethal doses for every particular taxonomic group may be considerably different.

Three species of Penicillium, Aspergillus and Cladosporium genera, 2 species of Alternaria and Fusarium and 1 species of Rhizopus and Paecilomyces genera were tested. Model waters were inoculated with spores of the mentioned monocultures. Three heterocultures: Aspergillus niger, Fusarium aquaductum and Paecilomyces varioti; Penicillium notatum, Aspergillus flavus, and Alternaria tenuis; Alternaria tenuis, Cladosporium fulvum and Rhizopus stolonifer were tested as well. The final spore concentration in water before the irradiation was approximately $10^{4} \cdot 1^{-1}$. The effects of various doses of UV radiation on the spores' germination and on the character of growth of mycelium were evaluated using cultivation methods. Our results show those bactericidal doses of UV radiation often effect stimulatory on the germination, growth rate and fructification of tested soil microfungi in heterocultures. These microfungi were able to highten their growth and germination after very high doses of UV radiation. These experiments indicate the doses of UV radiation necessary for elimination of heterogenous fungal contamination may be different from lethal doses for monocultures of the same species. Our results confirm the necessity to determine the disinfection doses of UV radiation for every water experimentally, not only by theoretical calculation.
\end{abstract}




\section{Introduction}

Microbiological contamination of water biotops by non-typical terrestrial organotrophic organisms is one of the consequences of antropogenic pollution of nature. Filamentous soil fungi belong also to such contaminants. Microscopic fungi are relatively common organisms in water environment [e.g. 3, 4, 5, 7, 10, $11,15,16,17,18,19,20$ and 21]. Microscopic fungi have been recovered from diverse remote and aquatic habitats including lakes, ponds, rivers, streams, wastewaters, well waters and aquatic sediments [6]. These organisms have been found in potable water [e.g. 3, 4, 8, 9, 11, 15, 16, 17, 18, 19 and 20] and on the inner surface of distribution system pipes [14]. Spores of many soil fungi may pass through the drinking water treatment processes. It is generally known, that soil fungi, as potential pathogens or producers of mycotoxins may have adverse impact on human health. From the all examined water samples 51 genera of filamentous soil fungi were isolated and identified by routine cultivation and microscopic methods [3]. Fungal contaminants were found in $44 \%$ samples of chlorinated potable water in one region [4]. This high incidence is in direct connection with the general deterioration of environmental quality. Due to this reality it is necessary to take microfungi into account especially by production of drinking water. Until recently, little or no attention has been paid to their occurrence and role in distribution system of potable water.

Disinfection of drinking water for the destruction or deactivation of diseaseproducing microorganisms is necessary. For many years the application of chlorine has been the most widely used procedure to provide microbiologically pure drinking water. However, many methods of chemical treatment involve the handling of hazardous materials, which are difficult to control and monitor. Increasingly, there are reports that most chemical desinfectants and their coproducts shown to have possible long-term damaging effects on humans [e.g. 12, 22]. Therefore processes based on non-chemical methods are undergoing rapid development. These technologies include UV radiation, reverse osmosis, haeting, freezing and so forth [13]. Irradiation with UV light is a promising method of disinfection. Artificial radiation with wavelengths of 240 to $290 \mathrm{~nm}$ causes photochemical reactions in the RNA and DNA of organisms, causing their inactivation [7]. Ultraviolet water disinfection has been succesfully practicesed without negative consequences. This method is preferred to chlorination or other chemical treatments because of it do not produce secondary more toxic substances [1]. UV radiation does not cause any odour or taste. Its only disadvantage that the UV effect is not prolonged in the distribution system.

The objective of this work was to evaluate effects of various UV doses on some fungal spores occurring most often in drinking waters in Slovakia.

\section{Material and methods}

The influence of UV radiation on fungal spores in water was tested in laboratory conditions. Experimental model waters were prepared from sterilised tap water 
inoculated with one type of spores only or with a mixture of spores belonging to three different fungal genera. The concentration of spores in waters before irradiation was approximately $10^{4} \cdot 1^{-1}$. The prepared samples were irradiated in an encapsulated emitter, in which water by-passed a gas discharges lamp in $3 \mathrm{~cm}$ layer. The total water volume in the work area of the emitter was approximately 3 1 .

Irradiation doses of $25 \mathrm{~W}$ radiation source, $3 \mathrm{~cm}$ water layer, and $50 \mathrm{~cm}$ jacket height were calculated after the following formula:

$$
D=\frac{E . t}{F}\left[\mu W \cdot s . \mathrm{cm}^{-2}\right]
$$

$$
\begin{array}{ll}
E=E_{0} \cdot e^{-\alpha . x}[\mathrm{~W}] & \mathrm{t}=\text { exposure time }[\mathrm{s}] \\
\mathrm{E}_{\mathrm{o}}=0.6 .25 & \mathrm{x}=\text { water layer thickness in emitter } \\
\mathrm{F}=\text { irradiated area }\left[\mathrm{cm}^{2}\right] & \alpha=\text { absorption coefficient }=0.1
\end{array}
$$

One $\mathrm{ml}$ of prepared samples was irradiated within interval from 0 to $360 \mathrm{~min}$ (Table 1). The spread plate technique was used next. For the purpose of filamentous fungi cultivation Sabouraud and Czapek-Dox agar were used [10]. In the course of seven day cultivation on both media at laboratory temperature (20 $22^{\circ} \mathrm{C}$ ) the spore germination, growth and pigmentation of mycelia were evaluated.

Table 1. UV dose dependence on irradiation time

\begin{tabular}{|l|c|c|c|c|c|c|c|}
\hline Time (min.) & $\mathbf{0}$ & $\mathbf{3}$ & $\mathbf{5}$ & $\mathbf{3 0}$ & $\mathbf{6 0}$ & $\mathbf{1 2 0}$ & $\mathbf{3 6 0}$ \\
\hline $\begin{array}{l}\text { UV dose } \\
(\mu \text { W.s.cm }\end{array}$ & 0 & 2123.4 & 3539.0 & 21234.0 & 42469.0 & 84938.0 & 254810.0 \\
\hline
\end{tabular}

\section{Results and discussion}

Among all the current methods of water disinfection, ultraviolet sterilisation can be considered as the most effective and pollution free. UV radiation is effective on all microbial forms in water but lethal doses for every particular taxonomic group may be considerably different (Table 2). Their value affects the character of pertinent organism and many physical and chemical factors as well. The UV radiation may cause mutagenic effects especially in sublethal doses $[2,14]$ and microorganism destruction (the lethal effect) is depends upon correct UV dosage (Table 2). It is therefore necessary determine the UV dose needed for elimination of particular microbial species under concrete conditions experimentally.

Three species of Penicillium, Aspergillus and Cladosporium genera, 2 species of Alternaria and Fusarium and 1 species of Rhizopus and Paecilomyces genera were tested. The most sensitive to UV radiation were spores of Fusarium aquaductum. The UV dose of $21234.0 \mu$ W.s.cm ${ }^{-2}$ was sufficient to eliminate its spores. They 
were completely inactivated after $30 \mathrm{~min}$ irradiation (Figure 1). On the other hand Fusarium moniliforme spores were the most resistant. Their growth was even stimulated after $6 \mathrm{~h}$ irradiation (the $\mathrm{UV}$ dose $=254810.0 \mu \mathrm{W} . \mathrm{s.c \textrm {cm } ^ { - 2 }}$, Figure 1).

Table 2. Recommended UV doses for elimination of some microorganisms (DESUVA)

\begin{tabular}{|l|c|c|}
\hline \multirow{2}{*}{ Microorganismus } & \multicolumn{2}{|c|}{ dose $\left(\mu \mathrm{M} / \mathrm{cm}^{2}\right)$} \\
\cline { 2 - 3 } & $90 \%$ effect & $100 \%$ effect \\
\hline Bacteria & & 6600 \\
\hline Escherichia coli & 3000 & 10500 \\
\hline Pseudomonas aenuginosa & 5500 & 6600 \\
\hline Proteus vulgaris & 2600 & 10000 \\
\hline Salmonella & 5400 & 12300 \\
\hline Yeast & & 17600 \\
\hline Saccharomyces ellipsoideus & 7300 & \\
\hline Saccharomyces sp. & 9700 & 99000 \\
\hline Filamentous fungi & & 330000 \\
\hline Aspergillus flans & 54000 & 220000 \\
\hline Aspergillus niger & 180000 & \\
\hline Rhisopus nigricans & 120000 & \\
\hline
\end{tabular}

Aspergillus species were resistent to UV radiation (Figure 1,3 and 4). Their growth was ripened as well as stimulated and changes in the pigmentation were observed. Only A. flavus did not grown after the UV dose $254810.0 \mu \mathrm{W} . \mathrm{s.cm}^{-2}$ (Figure 2). Effective UV doses for A. flavus corresponded with UV doses given in Table 2. A. niger spores were more resist to ultraviolet irradiation than A. flavus (Table 3, Figure 2 and 3). Effective UV doses for $A$. niger did not corresponded with UV doses given in Table 2. At the dose $254810 \mu \mathrm{W} . \mathrm{s} . \mathrm{cm}^{-2}$ A. niger spores germinated and changes in the pigmentation were evident. Spores of particular species of Penicillium were able to grow after $6 \mathrm{~h}$ irradiation (Table 3). Lower doses of UV radiation up to $21234 \mu \mathrm{W} . \mathrm{s} . \mathrm{cm}^{-2}$ manifested themselves in ripened growth and changes in the pigmentation (Table 3). Among the tested species of genus Cladosporium the most resistant were C. fulvum spores (Table 3).

Interesting results provided our experiments carried out with heterogenous model waters. For example data in Figures 3 - 5 come from experiments with combination of model water contained Aspergillus niger spores with Paecilomyces varioti and Fusarium aquaductum. A. niger spores were stimulated in all tested irradiation times and UV doses as well (Figure 3). The growth of Fusarium aquaductum spores was eliminated in monoculture but stimulated in heteroculture (UV irradiation dose $21234.0-254810.0 \mu \mathrm{W} .{\mathrm{s} . \mathrm{cm}^{-2}}^{-2}$. Paecilomyces varioti spores were able to grow and sporulated after the UV dose $-254810.0 \mu \mathrm{W} . \mathrm{s} . \mathrm{cm}^{-2}$ in this heteroculture. In other UV doses the growth of $P$. varioti in heteroculture was 
comparable with the growth in monoculture. Penicillium notatum, Aspergillus flavus, and Alternaria tenuis. The germination and growth of spores were evidently stimulated even after applying of the highest dose of UV radiation (Figure 3, 4 and 5). The spores of Alternaria tenuis, which were present in other model waters (with Cladosporium cladosporioides and Rhizopus stolonifer) revealed after irradiation in every different combination also different growth.

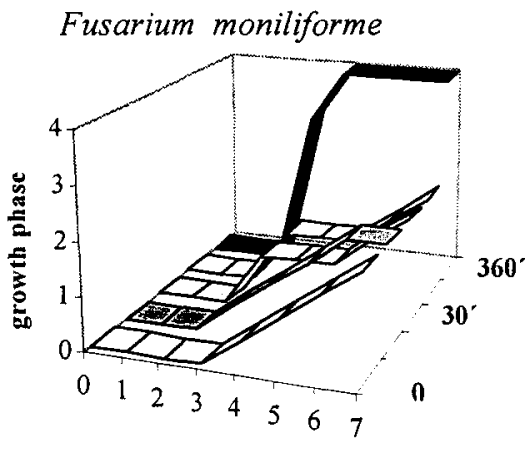

days of cultivation

\section{Fusarium. aquaductum}

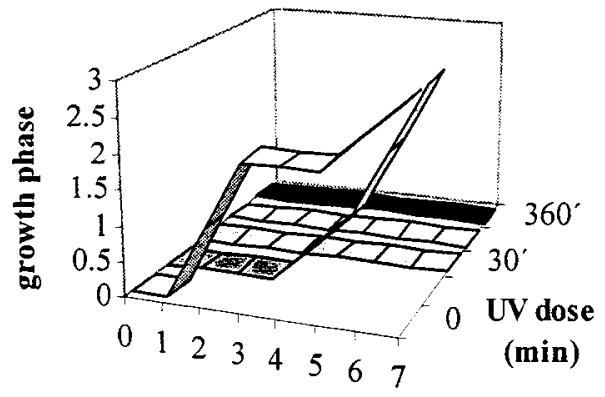

days of cultivation

Figure 1: Germination and growth of the Fusarium spores in monocultures after UV irradiation.

है

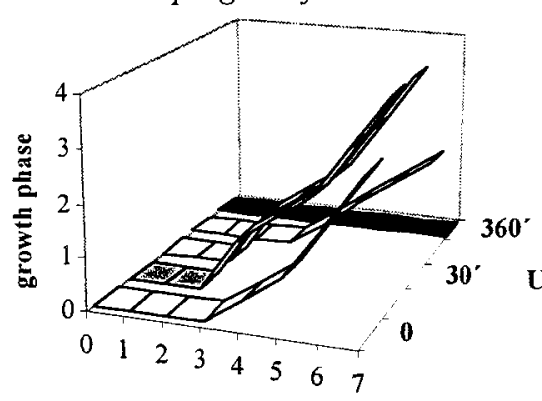

days of cultivation
Aspergillus nidulans

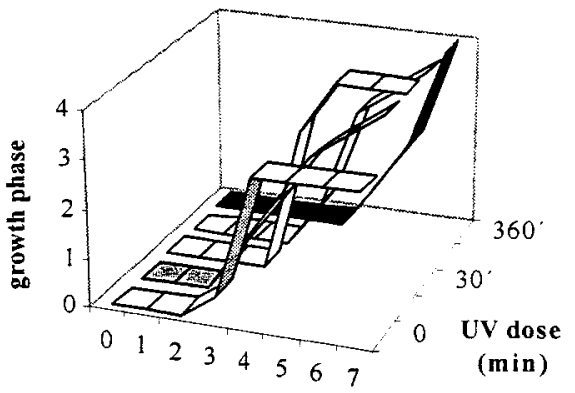

days of cultivation

Figure 2: Germination and growth of the Aspergillus spores in monocultures after UV irradiation. 
Table 3. Germination and growth of the fungal spore monocultures seven days after UV irradiation.

\begin{tabular}{|c|c|c|c|c|c|c|c|}
\hline \multirow[t]{2}{*}{ Species of fungi } & \multicolumn{7}{|c|}{ Effects of UV irradiation (min.) } \\
\hline & 0 & 3 & 5 & 30 & 60 & 120 & $\overline{360}$ \\
\hline Penicillium notatum & +++ & ++ & $+1+$ & $+1+1$ & ++ & ++ & \\
\hline$P$. digitatum & ++ & $+++!$ & $+++!$ & ++ & + & + & - \\
\hline P. chrysogenum & $+1+$ & +++ & $+++!$ & +++ & + & - & - \\
\hline Aspergillus flavus & +++ & $+++S !$ & $++\mathrm{S} !$ & $+++S !$ & ++ & ++ & - \\
\hline A. nidulans & $1++$ & $+++S !$ & $+++S !$ & $+++!$ & $+++S !$ & $+1+!$ & $+++!$ \\
\hline A. niger & $+1+$ & $+++S !$ & $+++S !$ & $+++S !$ & $++\mathrm{S} !$ & $+++!$ & $+++!$ \\
\hline Alternaria tenuis & + & ++ & +++ & ++ & ++ & ++ & + \\
\hline Alternaria sp. & + & +++ & +++ & +++ & +++ & ++ & + \\
\hline Rhizopus stolonifer & $1++$ & $+++S !$ & $++\mathrm{S} !$ & +++ & +++ & +++ & - \\
\hline Fusarium aquaductum & +++ & +++ & +++ & - & - & - & - \\
\hline F. moniliforme & +++ & ++ & ++ & ++ & ++ & ++1 & $+1+S$ \\
\hline Cladosporium fulvum & ++ & ++ & ++ & $+++S$ & $+++S$ & +++ & +++ \\
\hline C. herbarum & +++ & +++ & ++1 & $+1+S$ & $+++S$ & $+++S$ & - \\
\hline C. cladosporioides & $+1+$ & ++ & ++ & +++ & $+1+$ & ++1 & - \\
\hline Paecilomyces varioti & ++ & +++ & +++ & $+++!$ & $+1+!$ & + & - \\
\hline
\end{tabular}

Legend:

- without growth

+ growth of sterile mycelium

++ growth and sporulation
+++ Ripened growth

$\mathrm{S}$ stimulation of growth

! changes in the pigmentation

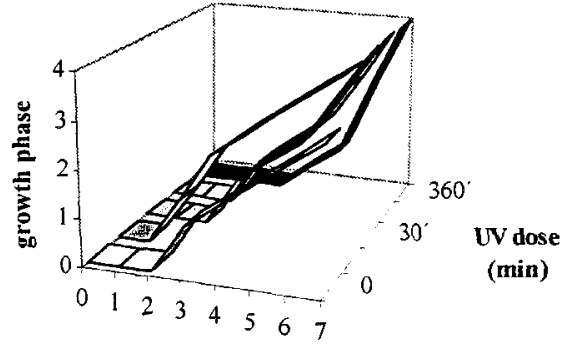

days of cultivation

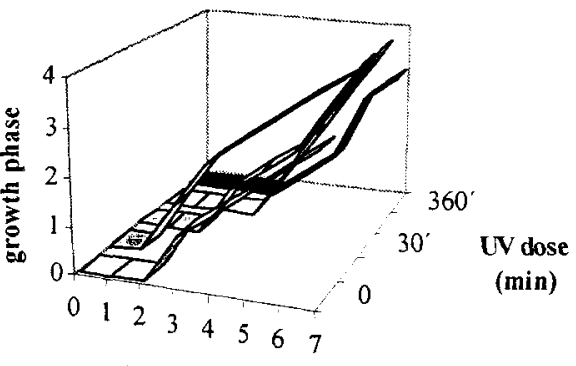

days of cultivation

In the heteroculture with

Fusarium aquaductum and

monoculture

Paecilomyces varioti

Figure 3: Comparison of Aspergillus niger germination and growth in mono- and heteroculture after UV irradiation (Growth phase: 1 growth of sterile mycelium, 2 growth and sporulation, 3 ripened growth, 4 stimulation) 
These results show that bactericidal doses of UV radiation often effect stimulatory on germination, growth rate and fructification of tested microfungi in heterocultures (Table 2 and 3). These microfungi were able to stimulate growth and germination after very high doses of UV radiation as well.

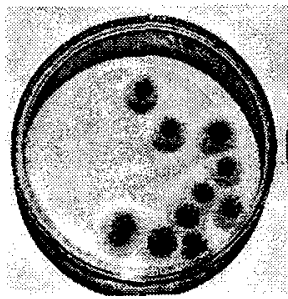

$\mathrm{K}$

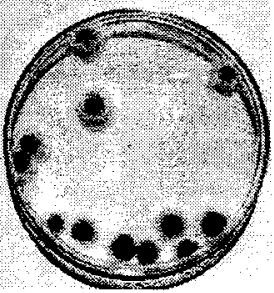

$3 \mathrm{~min}$.

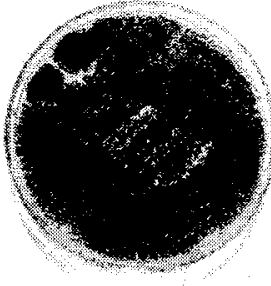

$30 \mathrm{~min}$.

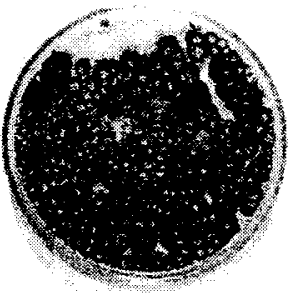

$60 \mathrm{~min}$.

Figure 4: The growth of Aspergillus niger on Sabouraud agar after UV irradiation ( $\mathrm{K}$ - without irradiation, $3 \mathrm{~min}$ irradiation, $30 \mathrm{~min}$ irradiation and $60 \mathrm{~min}$ irradiation).

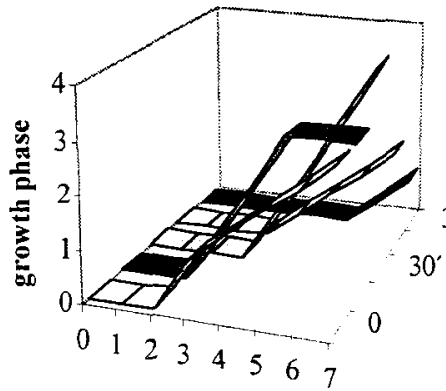

days of cultivation

In the heteroculture with

Fusarium aquaductum and Asvergillus niger

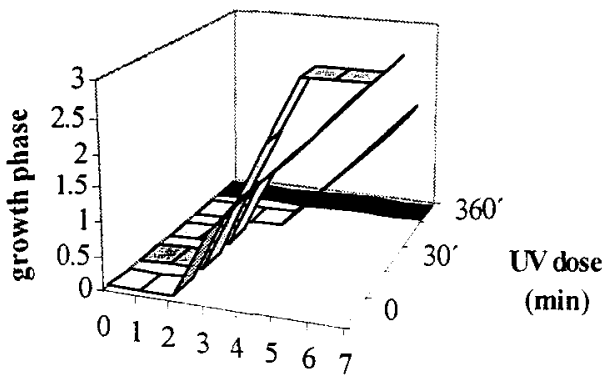

days of cultivation

monoculture

Figure 5: Comparison of Paecilomyces varioti germination and growth in monoand heteroculture after UV irradiation (Growth phase: 1 growth of sterile mycelium, 2 growth and sporulation, 3 ripened growth, 4 stimulation)

These experiments indicate the doses of UV radiation necessary for elimination of heterogenous fungal contamination may be different from doses lethal for 
monocultures of the same species. It is therefore necessary to determine experimentally and individually the effective doses for every type of contaminated water.

\section{Conclusions}

Microscopic fungi are relatively common organisms in drinking water [e. g 3, 4, 9, $11,15,17,20$ and 21]. Ultraviolet irradiation of water has been succesfully practised without negative consequences. However the effective doses for every particular taxonomic group may be considerably different.

Results indicated that UV radiation shows different effects on fungal spores.

UV doses necessary for elimination of fungal spores present in drinking water are several times higher than bactericidal ones

Our results have shown that bactericidal doses of UV radiation often effect stimulatory on germination, growth rate and fructification of tested soil microfungi in heterocultures. These microfungi were able to stimulate growth and germination after very high doses of UV radiation.

These experiments indicate the doses of UV radiation necessary for elimination of heterogenous fungal contamination may be different from lethal doses for monocultures of the same species. It is therefore necessary to determine the effective doses for every disinfected water experimentally and individually.

Considering the soil fungi are potential pathogens and many of them can produce toxins, bactericidal UV doses may cause undesirable mutational effects.

UV radiation applied for the water disinfection after standard microbiological criteria of water quality (Enterobacteriaceae) may worsen the quality of irradiated water from the hygienic, health, and distributive point of view.

Therefore UV doses used for water disinfection should be determined and controlled experimentally in dependence with the character of present spores.

The UV radiation may cause mutagenic effects especially in sublethal doses [2, 14]. To acchieve the microorganism destruction (the lethal effect) it is necessary to apply sufficient UV dosage. It is therefore necessary to determine the UV dose needed for elimination of particular microbial species under concrete conditions experimentally.

This work was supported by Grant agency VEGA 1/7135/20 and NRL 4105

\section{References}

[1] ANGEHRN, M. Ultraviolet Disinfection of Water, Aqua, 2, 109-115, 1984.

[2] BETINA, V. \& NEMEC, P. Elementary Microbiology. Alfa, p. 477, 1977.

[3] FRANKOVA, E., Isolation and identification of filamentous soil Deuteromycetes from the water environment. Biologia, 48, $287-290,1993$.

[4] FRANKOVÁ, E., HORECKÁ, M. Filamentous soil fungi and unidentified bacteria in drinking water from wells and water mains near Bratislava. Microb. Res. 150,3 , pp. 311-313, 1995. 
[5] Franková, E., TÓTHOVÁ, L. A ŠIMONOVIČovÁ, A. Monitoring of mycetic revitalization of natural ecosystem, Ekologia Bratislava, pp. 20-27, 1998.

[6] GReENBERG, A.E., Clesceri, L.S \& EATON, A.D. (eds). Standard methods for the examination of water and wastewater. APHA Washington, 1992.

[7] HARM, W. Biological effects of ultraviolet radiation. Cambridge university Press, New York, 1980.

[8] Häuslerová. J. Micromycetes in waterworks (in Czech). Proc. of the Aktuální otázky vodárenské biologie, Praha, pp. 65-74, 1994.

[9] HINZELN, F. \& BLOCK, J.C. Yeast and filamentous fungi in drinking water. Environ. Tech. Letters, 6, $101-107,1985$.

[10] HOOG, G. S. \& GUARRO J., (eds.) Atlas of clinical fungi. Centralbureau voor Schimmelcultures, Universitat Rovira i Virgili, p. 720, 1995.

[11] JESENSKÁ, Y., HRDINOVÁ, I. Microscopic fungi in surface water and their importance for the practice of the hygiene service (in Slovak). Čs. Hyg. 27, pp. $127-128,1982$.

[12] Krasner, S., W., McGuire, M., J., Jacangelo, J. G., Patania, N. L., REAGAN, K. M. \& AIETA, E. M. Journal AWWA, Research and Technology, 1989.

[13] KIELY, G. Environmental engineering. McGraw-Hill, Berkshire, G.B., pp. 437, 1997.

[14] MELICHERČíK, J. \& MELICHERČíKOVÁ, V. Germicide radiators - possibility of

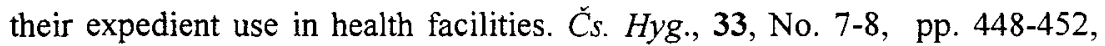
1988.

[15] NAGY, L.A. \& OLSON, B.H. The occurrence of filamentous fungi in water distribution systems. Can. J. Microbiol., 28, pp. 667-670, 1982.

[16] NiEMI, R.M., KUNTH, S. \& LUNDSTROM, K. Actinomycetes and fungi in surface waters and potable water. Appl. Environ. Microbiol., 43, pp. 376-379, 1982.

[17] Pavlosek, J., Ditrich, O., OTČEnAŠEK, M. \& VondRÁČEK, V. The observation of microscopic fungi in drinking waters (in Czech) $\check{C} s$. Hyg., 29, pp. $291-299,1984$.

[18] RosenZWeig, W.D., MINNIGH H. \& PIPES W.O. Fungi in potable water distribution systems. J. Amer.Water Works Assoc., 78, pp. 53 - 55, 1986.

[19] Tóthová, L. \& FranKOVÁ, E. Isolation and identification of filamentous micromycetes from the water. Proc. of the IAWQ-IWSA workshop on Separation of microorganisms from water and wastewater. Amsterdam, pp. 71-77, 1995.

[20] TÓTHOVÁ, L., ProKš, M. \& Franková, E., Problémy s kontamináciou mikroskopickými hubami v praxi. SOVAK, 5, pp. $13-14,1999$.

[21] TÓTHOVÁ, L. Additional knowledge on the occurrence of micromycetes in the aquatic environment (In Slovak). Práce a štúdie VÚVH, . 137, p. 124, 2000.

[22] VINCOLI, W., V. Risk management for Hazardous Chemicals (RMHCH), CDROM, 1997. 